\title{
Factors Affecting Adoption and Use of Mobile Banking Services in Zambia Based on TAM Model
}

\author{
Lute Sakala ${ }^{1}$, Jackson Phiri ${ }^{2}$ \\ ${ }^{1}$ Graduate School of Business, The University of Zambia, Lusaka, Zambia \\ ${ }^{2}$ Department of Computer Science, School of Natural, The University of Zambia, Lusaka, Zambia \\ Email: luliya90@gmail.com, jackson.phiri@cs.unza.zm
}

How to cite this paper: Sakala, L. and Phiri, J. (2019) Factors Affecting Adoption and Use of Mobile Banking Services in Zambia Based on TAM Model. Open Journal of Business and Management, 7, 1380-1394.

https://doi.org/10.4236/ojbm.2019.73095

Received: June 6, 2019

Accepted: July 23, 2019

Published: July 26, 2019

Copyright $\odot 2019$ by author(s) and Scientific Research Publishing Inc. This work is licensed under the Creative Commons Attribution International License (CC BY 4.0).

http://creativecommons.org/licenses/by/4.0/

\section{(c) (i) Open Access}

\begin{abstract}
The aim of the study was to identify the factors that affect the adoption and use of mobile banking services in Zambia based on the Technology Acceptance Model. Mobile banking a product offered under electronic banking services was the focus of the study. A quantitative research design was used, with a sample size of 384 respondents who held retail savings and current accounts that were eligible for mobile banking services in three commercial banks. A survey questionnaire was used as the primary data collection tool and the data collected was analysed using the IBM SPSS statistics. The results of study were that there is a significant positive relationship between perceived ease of use, perceived usefulness, user attitude, external variables, user intention and system use. The regression results further showed that, the independent variables in the TAM model, perceived ease of use, perceived usefulness, external factors, user attitude and user intention account for $47 \%$ of the variance in the factors that determine the use of electronic banking technologies such as mobile banking. The study recommends that commercial banks and the providers of mobile banking services need to improve the perceived ease of use, perceived usefulness, external factors; and promote positive user attitude and user intention. This would result in improved adoption and use of mobile banking services. They should also provide information on how to access and use these services.
\end{abstract}

\section{Keywords}

Adoption and Use, m-Banking Services, TAM Model, Zambia

\section{Introduction}

The banking sector has evolved over time with the introduction of modern In- 
formation technology which has lead to digitalisation in the sector. This was done in order to keep up with growing social trends, shifting customer needs, market trends and competition. Digitalisation of the banking industry worldwide has resulted in the shift from traditional banking to the use of alternate banking channels like merchant services, internet banking, agency services, Automated teller machines (ATMs) and the use of Mobile banking also referred to as m-banking.

[1] defines m-banking as an application that has resulted from the widespread use of computer technologies that are shaping all aspects of everyday life. It is as a result of organizations that are connected to the internet deciding to offer exceptional customer service. It describes the banking services that the user can perform via a mobile device ubiquitously at anytime and from anywhere. In order for users to access their accounts, they need a mobile device and network connectivity.

Today customers' interactions with their banks are done through multiple touch points like branches, ATMs, telephone banking, internet banking and $\mathrm{m}$-banking. These provide efficient ways of selling products and offering services to their clients [2]. Digitalisation of the banking sector has revolutionized how financial transactions are performed leading to the customer's experience being enhanced by making banking easy, quick, convenient and cheaper [3]. To add on, the evolution from a focus on local centric (branches and ATM) place-centric (internet banking) and then to equipment-centric (accessible anywhere, 24 Hours per day and 7 days a week) has yielded benefits in the form time savings and shorter branch queues and that clients are brought closer to their banks by the use of m-banking.

Apart from bringing clients closer to their banks, the introduction of e-banking services has also lead to greater financial inclusion. Through m-banking, clients in developing countries that had no access to formal financial services both the unbanked and underserved are enabled through digital access [4].

There is great potential for the growth of Digital Financial Services (DFS) through the use of e-banking services in Zambia. The gap that exists between the presence of commercial banks and their capacity to service the Zambian market can be narrowed down through the use of e-banking services such as m-banking. [5] reports that, out of the adult population in Zambia, 11 percent own mobile money accounts and only 4 percent use mobile money. Recent data, however, show that DFS uptake among Zambian adults has increased significantly from 8 percent in 2015 to 18 percent in 2016. Uptake of mobile money, and consequently DFS, is constrained by lack of awareness and means of accessing the services.

Mobile network providers in Zambia have greater reach than traditional banks in offering DFS. This is because the branch network of commercial banks is clustered around Lusaka and Copperbelt provinces. This implies that the commercial bank presence in the other 8 provinces is not as dominant as in the 
two provinces. [6] reports that, the bank branch network in Zambia is concentrated in Lusaka and the Copperbelt Provinces which accounts for 65.3 per cent of the total banking sector branches, followed by Southern Province which accounted for 11.6 per cent. Luapula Province had the lowest branch coverage with only 2.1 per cent of total banking sector branches. [7] reports that, recent statistics released by Zambia Information and Communications Technology Authority (ZICTA) suggests that Zambia which has a population of 16 million is home to 13.4 million mobile subscribers. This represents a penetration rate of 81.92 percent which implies that the telecommunications sector is near saturation. Also, the number of mobile internet users in the country has increased to 7.7 million from 7.1 million, representing a 47.08 percent penetrate rate.

Despite m-banking services being available in Zambia, and offered by commercial Banks to their retail clients in an effort to transition from traditional banking to offering digital financial services potential users are still not adopting and using these services. This has negatively affected these potential users because using m-banking services makes performing financial transactions and accessing financial information faster, more convenient and cheaper than traditional banking.

Solutions to this problem can be found by conducting research on factors that affect the adoption and use of m-banking services in Zambia based on the Technology Acceptance Model (TAM).

This article is organized as follows; firstly the theoretical background that guided the research will be out lined, then a review of the empirical literature. Thereafter, the methodology used in the study will be explained. Next results of the study and a discussion of those results will be given. Lastly, the conclusions drawn and recommendations given by the study will be outlined.

\subsection{Theoretical Framework}

There are a number of $\mathrm{m}$-banking adoption models that explain the factors that influence the adoption and use of m-banking technologies. Among these models are The Theory of Diffusion of Innovations, Theory of Reasoned Action (TRA), and Theory of planned behaviour (TPB), (Decomposed TPB) and TAM model.

The theory of Diffusion of innovations as proposed by Everett Rodgers explains how technology innovations are accepted and adopted by users [8]. This model explains how an innovation is communicated through certain channels over time by a process known as diffusion. This goes through several stages: understanding, persuasion, decision, implementation; and confirmation. These stages are depicted by an $\mathrm{S}$ shaped adoption curves that are divided into five parts which are: early adopters, early majority, late majority and laggards.

Another theory is TRA which was developed by Fishbein and Ajzen in 1975. It explains the relationship between attitude and behaviour in human actions. [9] defined attitude as the individual's evaluation of an object, belief as a link between an object and some attribute, whereas behaviour was looked at as being a 
result or intention. The theory states that, attitudes are affective and based upon a set of beliefs about the object of behaviour. The theory introduces another factor in predicting user behaviour that of a person's subjective norm. This is explained as being what potential users perceive that their community will think of their behaviour.

Developments were made on the TRA as theorized by Fishbien and Ajzen in 1975. He proposed TPB which developed on the relationship between attitude and behaviour in human actions by introducing a new factor: perceived behavioural control which can be used to predict behaviour. Perceived behavioural control is explained as the behaviour that influences intention. It is a factor that is present in the theory of planned behaviour and not in the theory of reasoned action; this is the point of contrast for the two theories [10].

Another theory that can be used to explain user's adoption and use of new technologies is (Decomposed TPB) as theorized by Taylor and Todd in 1995. The theory contains three main factors that can be used to explain what influences behavior intention and actual behavior adoption. These factors are: attitude, subjective norms; and perceived behavior control [11].

Lastly, TAM is another model that can be used to explain user's behaviour towards the adoption and use of $\mathrm{m}$-banking services in Zambia. It was developed from the theory of reasoned action and so adapted some of its principles to the context of user acceptance of a system.

[12] argues that TRA provided a useful model that could predict and explain the actual behavior of an individual. Ten years later, [13] took the same model and adapted it to the context of user acceptance of a system, in order to develop TAM. Davies considered that the actual use of a system is a behavior and thus the theory of reason action would be a suitable model to explain and predict that behavior. Davies however, made two main changes to the TRA model. Firstly, he did not take subjective norm into account in predicting the actual behavior of a person. He suggested TRA acknowledged that subjective norm was the least understood aspect of the theory, and that it had uncertain theoretical status.

[13] stated that users' motivation can be explained by three factors: Perceived Ease of Use (PEU), Perceived Usefulness (PU), and Attitude toward using the system. He went on to define PE as the degree to which an individual believes that using a particular system would enhance his or her job performance and defined PEU as the degree to which an individual believes that using a particular system would be free of physical and mental effort. In his research, he hypothesized that the attitude of a user toward a system was a major determinant of whether the user will actually use or reject the system. The attitude of the user, in turn, was considered to be influenced by the two major beliefs: PU and PEU, with PEU having a direct influence on PU. Finally, both these beliefs were hypothesized to be directly influenced by the system design characteristics.

Later on Davies refined his model to include other variables and modify the relationships that he had initially formulated. Overtime, other researchers gave 
their input regarding TAM which leads to it becoming a leading model in explaining and predicting system use. It has become so popular that it has been cited in most of the research that deals with user acceptance of technology [14].

The study used the TAM model in Figure 1, to identify the factors that affect the adoption and use of $\mathrm{m}$-banking services in Zambia.

\subsection{Empirical Review of Literature}

[3] argued that, by enhancing the quality of m-banking more users would be retained, potential adopters of m-banking would be attracted, with the consequence of enhancing individual performance, in turn. The findings were that the importance of use and individual performance has long been recognized by academics and practitioners in a variety of disciplines. The two most significant drivers of intention to adopt $\mathrm{m}$-banking are PEU and PU.

[15] conducted a study in Tanzania, investigating the factors influencing the adoption of mobile banking services in the unbanked population. A cross-sectional design was used by collecting data at a single point in time. Six variables based on TAM were used: PU, PEU, perceived trust, perceived cost, perceived risk; and social influence. The construct validity of the measurement items was established by using confirmatory factor analysis conducted using Structural Equation Modeling (SEM) and the reliability was established by using Cronbach's Alpha coefficient. The hypothesis was tested by using multiple regression analysis. The sample size used was 250 respondents selected from the study area. The study revealed that PU, perceived cost and social influence had a significant influence on the adoption of mobile financial services. PEU, perceived risk and perceived trust were found to have an insignificant influence on the adoption of mobile financial services.

In an empirical study on the use and adoption of mobile data services in South Africa and Mauritius, conducted by [16]. The research objective was to investigate the use and adoption of a number of data services including m-banking. According to the study some of the major inhibitors and obstacles to adoption and use are; inconvenience when a mobile phone is lost and everything has to be

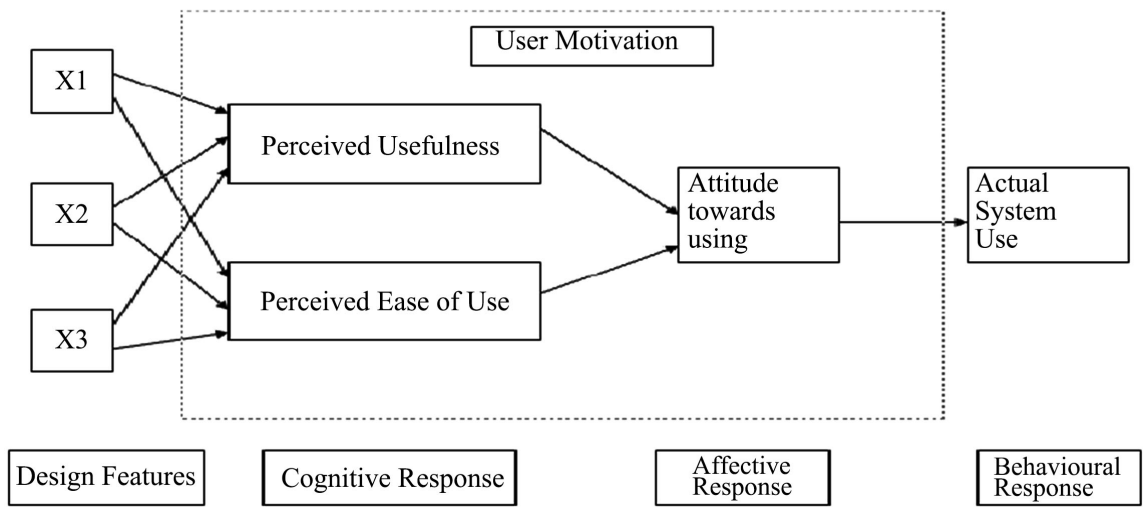

Figure 1. TAM model [13]. 
replaced, lack of skills and knowledge concerning the service and the poor design interface of the design. Both qualitative and quantitative research designs were used. The data was analysed using descriptive statistics and spearman rank correlation coefficient was used to test the null hypothesis. A research instrument was designed to assess the usage pattern of mobile data services in both countries. The targeted sample had two sub samples; The first consisting of University students considered as young, innovative, sophisticated and well networked users who are familiar with the mobile technology and the second came from the business environment where people are thought to achieve direct financial and time efficiencies from using the technologies. Despite the socio-economic differences in the two countries, many of the barriers identified were similar. The factors that encourage the use of $m$-banking that were identified in the study were: Lower prices of services, increased awareness of new services; and better reliability of services.

A study was conducted by [17] on mobile banking adoption and challenges in Nigeria with an analytical focus on Enugu state. The study revealed that the level of adoption was still low among the middle aged correspondents compared to the aged even though m-banking is a growing trend in Enugu. Among the recommendations offered were: a cashless policy should be vigorously pursued that would encourage the use of $\mathrm{m}$-banking, a massive awareness programme to publicise the purpose and benefits derivable from the use of mobile banking; and network failure should be checked regularly. According to the study, this would boost the level of adoption of mobile banking services because of the convience and accessibility offered by this banking platform.

[18] conducted a study on the determinants of consumers' intention to adopt mobile banking services in Zimbabwe. The findings were that PU, perceived self-efficacy, social influence, relative advantage and perceived compatibility all have a positive effect. Whilst perceived risk has a negative effect on behavioral intention to adopt mobile banking services in Zimbabwe: PEU, facilitating conditions, perceived complexity, perceived trialability, awareness-knowledge and demographic factors (gender, age, education and income) did not significantly influence behavioral intention to adopt mobile banking. PEU was found to positively influence PU, while perceived self-efficacy was found to have a positive effect on PEU. Behavioral intention was found to positively influence usage of mobile banking services in Zimbabwe.

[19] conducted an empirical study examing factors influencing e-banking adoption in Zambia. The study examined the influence of e-banking technology's PU, PEU and trust (safety and credibility) on e-banking adoption. The findings indicated that modified TAM was applicable to the Zambian scenario for assessing, monitoring and increasing the adoption of e-banking services and that that PU, PEU and trust significantly and positively influences attitude to e-banking. In turn attitudes to e-banking influence intention and the actual adoption of e-banking services.

[20] conducted a study aimed at filling in the gap that exists on the factors 
that influence the acceptance of mobile banking applications from a comprehension point of view that includes the theory of trust, risk and social image. The main determinants of user behavior were tested against variables such as how user friendly, social image, intention to adopt the technology, trust and many others. The findings were that PEU has a positive effect on the usefulness of the proposed application, attitude toward intention to use a mobile application has a positive effect as well and that there was no significance relationship between usefulness or risk and intention to use. The implications of these results are that communication campaigns aimed at increasing trust, mitigating risk and uncertainty among potential users can use the results in order to communicate effectively with target markets.

[21] conducted a research in Zambia, which was aimed at investigating the challenges of adopting the use of e-banking by customers. The results of the study found that e-banking usage dependent on the availability of e-banking information. This means that there is increased publicity on e-banking, it is expected that if many customers would use the service. The results also showed that education levels also have a statistically significant influence on e-banking usage. This means that the higher the level of education, the more the usage of e-banking services. This is in line with the technological acceptance model.

The study found that at $5 \%$ level of significant, concern for personal security was not related to usage of e-banking services.

[22] conducted a literature review on mobile banking adoption involving several studies for the period January 2005-March 2014 that used both qualitative and quantitative methods. During the review process, few constructs were identified that have not been covered in prior research but merit consideration. The research findings were that there was some synergy between satisfaction and trust also emerged from a few studies that report that trust significantly affects the degree of satisfaction and is thus an important variable for m-banking environments. Furthermore, studies conducted in developing countries identify social and culture factors as strong influences on m-banking adoption. Similarly, combining these factors with a range of demographic factors indicates that the impact of social and cultural features is significant.

Literature on this topic was reviewed to establish how deep this topic has gone and how researchers have researched and concluded on this topical issue of the relationship between adoption and use of e-banking and other variables such as, PEU, PU, external variables, attitude towards use and user adoption.

[23] The objective of the study was to assess the factors that influence the level of e-tax systems adoption in Zambia based on TAM Model. The focus of the study was Tax Online system used by domestic taxes division in rural Zambia. The sample size of 100 respondents was purposively selected from various taxpayers who were coming through Zambia Revenue Authority Internet bureau. The data collected from semi structured survey questionnaires was analysed using descriptive statistics. The findings were that, the E-tax system is useful, easy to use and secure. 
[24] conducted a study on the factors driving the adoption of e-banking services in Zambia based on the Unified Theory of Acceptance and Use of Technology (UTAUT). A baseline study involving 313 respondents was undertaken with the sample consisting of clients from five top commercial banks. The main data collection tool was a question that was administered to the respondents who were chosen using purposive sampling. Data collected was then analysed using SPSS descriptive analysis. The findings were that factors in the model such as effort expectancy, facilitating conditions, behaviour intention, and performance expectancy have a significant impact on adoption of e-banking services. Social influence was found to be non significant to user's intention to adopt e-banking services.

The literature reviewed on related studies has provided adequate knowledge on the phenomena adoption and use of m-banking. Although there has been a lot of empirical research on m-banking as a product of e-banking services and the benefits it has in developing nations with regards to financial inclusion, adoption and use. However, there is still a need to investigate the factors that affect the levels of adoption and use of $\mathrm{m}$-banking services specifically in Zambia.

\section{Methodology}

The research approach that was used was quantitative in nature. The researchers choose this method because a quantitative method was more appropriate for study as it involved testing the TAM model constructs. Also, reviewed literature under this study used the quantitative method [17] [18] [23].

The target population for this research was three top commercial banks in Zambia. The selection criteria were based on assets, profitability and brand presence. Purposive sampling was used to select the top three commercial banks in the Zambian market. One branch from Lusaka province was selected from each commercial bank.

Non probability sampling was used to select respondents in this study. A number of reviewed literature in the study used that method [18] [19] [20] [23] [24]. The researcher's strategy was to ask all respondents a primary question as to know whether they held a retail personal savings or current account that were eligible for m-banking in the three banks selected for the study. Respondents that had corporate accounts and retail accounts were not eligible for m-banking were asked no further questions.

The calculation for determining sample size for non probability sampling was used [25]. Table for determing sample size for a given population shows that the ideal sample size for an unknown population size is 384 . Due to the confidential nature of banking practices, the researcher was unable to access information as to the numbers of retail account holders who use e-banking services specifically m-banking and those that do not. In addition, the three commercial banks selected for the study have a large retail customer base. It is for these reasons that, the exact population size was not known. 384 respondents was adequate repre- 
sentation of the unknown population size of potential users of e-banking services specifically $\mathrm{m}$-banking in Zambia. The sample size $(\mathrm{N})$ was 384 respondents out of which 289 correctly completed questionnaires were returned. The number of respondents from Bank A was 114 representing $29.70 \%$ of the total sample, Bank B had 90 respondents which represented $23.40 \%$ and lastly Bank C had 87 respondents representing $22.10 \%$. 95 respondents $24.7 \%$ representing the number of questionnaires that were not completed.

The researcher used survey questionnaires to collect primary data. The researcher administered questionnaires to respondents by standing at the entrance of the three Lusaka branches and at ATM terminals to purposively have contact with retail clients.

Secondary data was collected from published and unpublished material, articles in print and electronic media, journals, and annual financial reports.

The MS excel and IBM SPSS Statistics version 23 was used to analyze the primary data collected. The specific statistical method that was used was descriptive statistics, inferential statistics from IBM SPSS Statistics. The analysed data was presented into tables.

\section{Results and Discussion}

This section gives the research results of the study from the descriptive, correlation and regression tests that were run.

Table 1, shows the attributes of the participants in the study.

Table 1. Sample profile.

\begin{tabular}{|c|c|c|c|}
\hline Variable & Description & Frequency & Percent \\
\hline \multirow[t]{2}{*}{ Gender } & Male & 171 & 59.20 \\
\hline & Female & 118 & 30.70 \\
\hline \multirow[t]{5}{*}{ Age } & $18-25$ & 58 & 20.10 \\
\hline & $26-35$ & 115 & 39.80 \\
\hline & $36-45$ & 67 & 23.20 \\
\hline & $46-55$ & 37 & 12.80 \\
\hline & Above 55 & 12 & 4.20 \\
\hline Education & Primary & 26 & 6.80 \\
\hline \multirow[t]{2}{*}{ Level } & Secondary & 83 & 28.70 \\
\hline & Tertiary & 180 & 62.30 \\
\hline Employment & Unemployed & 27 & 9.30 \\
\hline \multirow[t]{2}{*}{ Status } & Self Employed & 90 & 31.10 \\
\hline & Formally Employed & 172 & 59.50 \\
\hline M-banking & Yes & 214 & 74.0 \\
\hline Use & No & 75 & 26.0 \\
\hline \multirow[t]{5}{*}{ Frequency of use } & Always & 66 & 22.80 \\
\hline & Often & 75 & 26.0 \\
\hline & Sometimes & 59 & 20.40 \\
\hline & Rarely & 16 & 5.5 \\
\hline & Never & 73 & 25.30 \\
\hline
\end{tabular}




\section{Continued}

\begin{tabular}{llll}
\hline Reasons for Non-use & Not Registered & 19 & 27.50 \\
& Prefer Traditional banking & 12 & 17.40 \\
Complicated Registration Process & 11 & 15.90 \\
Lack of Trust & 4 & 5.8 \\
Difficult to use & 6 & 8.7 \\
Lack of Mobile phone & 8 & 11.6 \\
Unaware of Product & 3 & 4.3 \\
Service charges & 6 & 8.7 \\
\hline
\end{tabular}

\subsection{Correlation Analysis}

Table 2, highlights the results for the correlation analysis. When the output was put to 0.01 level two tailed test, it was found that there is a positive significant relationship between use of $\mathrm{m}$-banking services and perceived ease of use, perceived usefulness, user attitude, external factors, user intention, system use. There are positive significant relationships with the variables. This is in line with findings in other studies [13] [16].

The results show that relationships that exist between the following variables in the TAM model are positive significant ones.

The relationship of perceived ease of use with user attitude, $r(287)=0.521, \mathrm{p}<$ 001 as perceived ease of use of m-banking services increases, user attitude towards using the system increases.

Furthermore, perceived usefulness with user attitude, $\mathrm{r}(287)=0.747, \mathrm{p}<001$, as perceived usefulness of $\mathrm{m}$-banking services increases, user attitude towards use increases. Perceived ease of use with perceived usefulness, $\mathrm{r}(287)=0.581, \mathrm{p}<$ 001 as perceived ease of use of $\mathrm{m}$-banking services increases, perceived usefulness of $\mathrm{m}$-banking services increase.

Also, user attitude with user intention, $\mathrm{r}(287)=0.728, \mathrm{p}<001$ as user attitude towards use of m-banking services increases, user intention to adopt and use $\mathrm{m}$-banking services increases. This is the case with user intention with frequency of user, $r(287)=0.535, p<001$, increase in one variable leads to increase in the other variable.

\subsection{Regression Analysis}

The results of the regression analysis identified the variables in the TAM that have actual influence on the adoption and use of m-banking services in Zambia. Refer to Table 2.

The first two factors are statistically significant while the third one is not. In terms of relative contribution towards predicting attitude to e-banking use, the largest contribution is from perceived usefulness of use of e-banking services (Beta $=0.006, p<0.001)$, followed by perceived ease of use of e-banking services (Beta $=0.004, p<0.001)$, and lastly user intention towards use of e-banking systems (Beta $=0.528, \mathrm{p}<0.05)$ and user intention towards use of e-banking (Beta $=0.051, \mathrm{p}=0.051)$ have no significance. Refer to figure two. This is in line with 
other findings [17] but differ on user intention and user attitude having insignificant relationships.

In their individuality, the coefficients vary in significance and variance of significance with user attitude $(\mathrm{p}=0.051)$ and user intention $(\mathrm{p}=0.528)$ having a non-significant relationship with the dependant variable use of mobile banking system.

In the model summary of the regression test $\mathrm{R}$ Square $=0.470$ refer to Table 3 and Table 4; therefore the independent variables account for $47 \%$ of the variance in the mobile banking usage. This is to say the independent variables, perceived ease of use, perceived usefulness, user attitude, external factors, user intention as a group account for $47 \%$ of the variance for actual usage. They therefore predict $47 \%$ of what determines user adoption and use of m-banking.

Using the Anova table test and taking alpha as 0.05 refer to Table 5, the regression model for the variance of the predicators was significant, $\mathrm{F}(6282)=$ $41.71, \mathrm{p}<0.001$. The variance of the independent variables as a whole was therefore significant as it was less than the alpha.

Table 2. Correlation results.

\begin{tabular}{|c|c|c|c|c|c|c|c|c|c|}
\hline & & Usage & $\begin{array}{l}\text { Frequency } \\
\text { of use }\end{array}$ & PEU & PU & $\begin{array}{l}\text { User } \\
\text { attitude }\end{array}$ & $\begin{array}{l}\text { External } \\
\text { factors }\end{array}$ & $\begin{array}{c}\text { User } \\
\text { intention }\end{array}$ & System use \\
\hline \multirow{3}{*}{ Usage } & Pearson Correlation & 1 & $0.774^{\star *}$ & $0.491^{* *}$ & $0.579^{* *}$ & $0.535^{\star *}$ & $0.481^{* *}$ & $0.524^{\star *}$ & $0.562^{\star *}$ \\
\hline & Sig. (2-tailed) & & 0.000 & 0.000 & 0.000 & 0.000 & 0.000 & 0.000 & 0.000 \\
\hline & $\mathrm{N}$ & 289 & 289 & 289 & 289 & 289 & 289 & 289 & 289 \\
\hline \multirow{3}{*}{ Frequency of use } & Pearson Correlation & $0.774^{\star *}$ & 1 & $0.484^{\star *}$ & $0.606^{\star *}$ & $0.581^{\star *}$ & $0.450^{* *}$ & $0.535^{\star \star}$ & $0.517^{\star *}$ \\
\hline & Sig. (2-tailed) & 0.000 & & 0.000 & 0.000 & 0.000 & 0.000 & 0.000 & 0.000 \\
\hline & $\mathrm{N}$ & 289 & 289 & 289 & 289 & 289 & 289 & 289 & 289 \\
\hline \multirow{3}{*}{ PEU } & Pearson Correlation & $0.491^{\star *}$ & $0.484^{* *}$ & 1 & $0.581^{\star *}$ & $0.521^{\star *}$ & $0.227^{\star *}$ & $0.447^{\star *}$ & $0.457^{\star *}$ \\
\hline & Sig. (2-tailed) & 0.000 & 0.000 & & 0.000 & 0.000 & 0.000 & 0.000 & 0.000 \\
\hline & $\mathrm{N}$ & 289 & 289 & 289 & 289 & 289 & 289 & 289 & 289 \\
\hline \multirow{3}{*}{ PU } & Pearson Correlation & $0.579^{* *}$ & $0.606^{\star *}$ & $0.581^{\star *}$ & 1 & $0.747^{\star *}$ & $0.436^{* *}$ & $0.650^{* *}$ & $0.596^{* *}$ \\
\hline & Sig. (2-tailed) & 0.000 & 0.000 & 0.000 & & 0.000 & 0.000 & 0.000 & 0.000 \\
\hline & $\mathrm{N}$ & 289 & 289 & 289 & 289 & 289 & 289 & 289 & 289 \\
\hline \multirow{3}{*}{ User attitude } & Pearson Correlation & $0.535^{\star *}$ & $0.581^{* *}$ & $0.521^{* *}$ & $0.747^{\star *}$ & 1 & $0.466^{* *}$ & $0.728^{\star *}$ & $0.534^{* *}$ \\
\hline & Sig. (2-tailed) & 0.000 & 0.000 & 0.000 & 0.000 & & 0.000 & 0.000 & 0.000 \\
\hline & $\mathrm{N}$ & 289 & 289 & 289 & 289 & 289 & 289 & 289 & 289 \\
\hline \multirow{3}{*}{$\begin{array}{l}\text { External factors } \\
\text { affecting adoption }\end{array}$} & Pearson Correlation & $0.481^{* *}$ & $0.450^{* *}$ & $0.227^{\star *}$ & $0.436^{* *}$ & $0.466^{* *}$ & 1 & $0.515^{* *}$ & $0.355^{* *}$ \\
\hline & Sig. (2-tailed) & 0.000 & 0.000 & 0.000 & 0.000 & 0.000 & & 0.000 & 0.000 \\
\hline & $\mathrm{N}$ & 289 & 289 & 289 & 289 & 289 & 289 & 289 & 289 \\
\hline \multirow{3}{*}{ User Intention } & Pearson Correlation & $0.524^{\star *}$ & $0.535^{\star *}$ & $0.447^{\star *}$ & $0.650^{* *}$ & $0.728^{\star *}$ & $0.515^{\star *}$ & 1 & $0.567^{\star *}$ \\
\hline & Sig. (2-tailed) & 0.000 & 0.000 & 0.000 & 0.000 & 0.000 & 0.000 & & 0.000 \\
\hline & $\mathrm{N}$ & 289 & 289 & 289 & 289 & 289 & 289 & 289 & 289 \\
\hline \multirow{3}{*}{ System Use } & Pearson Correlation & $0.562^{\star *}$ & $0.517^{\star \star}$ & $0.457^{\star *}$ & $0.596^{\star *}$ & $0.534^{\star *}$ & $0.355^{\star *}$ & $0.567^{\star \star}$ & 1 \\
\hline & Sig. (2-tailed) & 0.000 & 0.000 & 0.000 & 0.000 & 0.000 & 0.000 & 0.000 & \\
\hline & $\mathrm{N}$ & 289 & 289 & 289 & 289 & 289 & 289 & 289 & 289 \\
\hline
\end{tabular}

${ }^{* *}$ Correlation is significant at the 0.01 level (2-tailed). 
Table 3. Regression results.

\begin{tabular}{|c|c|c|c|c|c|}
\hline \multicolumn{6}{|c|}{ Coefficients $^{\mathrm{a}}$} \\
\hline \multirow[t]{2}{*}{ Model } & \multicolumn{2}{|c|}{$\begin{array}{l}\text { Unstandardized } \\
\text { Coefficients }\end{array}$} & \multirow{2}{*}{$\begin{array}{c}\begin{array}{c}\text { Standardized } \\
\text { Coefficients }\end{array} \\
\text { Beta }\end{array}$} & \multirow[t]{2}{*}{$\mathrm{t}$} & \multirow[t]{2}{*}{ Sig. } \\
\hline & B & Std. Error & & & \\
\hline (Constant) & -3.630 & 0.459 & & -7.902 & 0.000 \\
\hline Percieved ease of use & 0.384 & 0.134 & 0.157 & 2.868 & $0.004^{\star *}$ \\
\hline Percieved usefulness & 0.387 & 0.139 & 0.205 & 2.796 & $0.006^{\star *}$ \\
\hline User attitude & 0.269 & 0.138 & 0.147 & 1.957 & 0.051 \\
\hline $\begin{array}{c}\text { External factors affecting } \\
\text { adoption }\end{array}$ & 0.372 & 0.108 & 0.178 & 3.448 & $0.001^{\star *}$ \\
\hline User intention & 0.073 & 0.116 & 0.044 & 0.632 & 0.528 \\
\hline System use & 0.289 & 0.106 & 0.156 & 2.729 & $0.007^{* *}$ \\
\hline
\end{tabular}

${ }^{\mathrm{a} D e p e n d e n t ~ V a r i a b l e: ~ U s e ~ o f ~ m-b a n k i n g . ~}$

Table 4. Residual statistics.

\begin{tabular}{|c|c|c|c|c|c|}
\hline \multicolumn{6}{|c|}{ Residuals Statistics $^{\mathbf{a}}$} \\
\hline & Minimum & Maximum & Mean & Std. Deviation & $\mathrm{N}$ \\
\hline Predicted Value & 0.18 & 4.81 & 3.16 & 1.022 & 289 \\
\hline Std. Predicted Value & -2.913 & 1.615 & 0.000 & 1.000 & 289 \\
\hline Standard Error of Predicted Value & 0.070 & 0.375 & 0.162 & 0.055 & 289 \\
\hline Adjusted Predicted Value & 0.14 & 4.84 & 3.16 & 1.022 & 289 \\
\hline Residual & -3.197 & 2.664 & 0.000 & 1.085 & 289 \\
\hline Std. Residual & -2.916 & 2.430 & 0.000 & 0.990 & 289 \\
\hline Stud. Residual & -2.937 & 2.496 & -0.001 & 1.002 & 289 \\
\hline Deleted Residual & -3.245 & 2.812 & -0.003 & 1.113 & 289 \\
\hline Stud. Deleted Residual & -2.978 & 2.520 & -0.002 & 1.005 & 289 \\
\hline Mahal. Distance & 0.162 & 32.759 & 5.979 & 4.970 & 289 \\
\hline Cook's Distance & 0.000 & 0.049 & 0.004 & 0.006 & 289 \\
\hline Centered Leverage Value & 0.001 & 0.114 & 0.021 & 0.017 & 289 \\
\hline
\end{tabular}

${ }^{a}$ Dependent Variable: use of $\mathrm{m}$-banking.

Table 5. ANOVA results.

\begin{tabular}{cccccc}
\hline \multicolumn{5}{c}{ ANOVA $^{\mathrm{a}}$} \\
\hline Model & Sum of Squares & $\mathrm{df}$ & Mean Square & F & Sig. \\
Regression & 300.933 & 6 & 50.155 & 41.715 & $0.000^{\mathrm{b}}$ \\
Residual & 339.060 & 282 & 1.202 & & \\
Total & 639.993 & 288 & & & \\
\hline
\end{tabular}

${ }^{a}$ Dependent Variable: use of m-banking, ${ }^{b}$ Predictors: (Constant), System Use, External factors affecting adoption, PEU, User attitude, User Intention, PU. 


\section{Conclusions and Recommendations}

In line with TAM model, intended and actual behaviours on m-banking are expected to result from the three attitudinal antecedents of m-banking use: perceived usefulness, perceived ease of use and user attitude [13].

The results for the correlation analysis were in line with TAM model. They revealed that, there is a significant positive relationship between use of m-banking services and perceived ease of use, perceived usefulness, user attitude, external factors, user intention; and system use when the correlation output is put to 0.01 level two-tailed test.

Furthermore, the results of the regression analysis revealed that perceived usefulness (Beta $=0.006, \mathrm{p}<0.001)$, perceived ease of use (Beta $=0.004, \mathrm{p}<$ 0.001 ), external factors (Beta $=0.001, \mathrm{p}=0.001$ ) of $\mathrm{m}$-banking services have a significant relationship with actual system use.

While the other variables user attitude (Beta $=0.051, \mathrm{p}=0.051$ ) and user intention (Beta $=0.528, p=0.05)$ had no significant relationship. Also, the research revealed that user attitude and user intention had no significant relationship with the other variables. In the model summary of the regression test ( $\mathrm{R}$ Square $=0.470$ ); therefore the independent variables, perceived ease of use, perceived usefulness, external factors, user attitude and user intention account for $47 \%$ of the variance in the mobile banking usage. This means that the independent variables in the TAM model predict $47 \%$ of the factors that determine the adoption and use of $\mathrm{m}$-banking.

In order to increase the adoption and use of m-banking services in Zambia, perceived usefulness of the services must be increased. Furthermore, the perceived ease of use of the services and external variables of the services must be highlighted this will lead to greater adoption and use of e-banking services. The regression results showed that the independent variables in the TAM model predict $47 \%$ of the factors that determine the adoption and use of m-banking.

The study made the following recommendations:

Commercial banks and providers of $m$-banking services need to promote the factors that affect the adoption and use of m-banking services in Zambia as identified in the study.

Commercial banks, financial institutions and the providers of DFS should create awareness of the benefits of $\mathrm{m}$-banking services that include: financial inclusion, easy access to m-banking services and convenience in performing transactions.

In order to increase the adoption and use of m-banking services commercial banks should provide information on how to access and use the services. If potential users of the services are given the knowledge on how to register and use the services, it becomes easier for them to use services and go on to adopt them.

Further works should consider a sample that includes the other provinces among which some are rural areas apart from Lusaka. Also, UTAUT model should be used to validate the research findings generated by this study. This is 
because, it has more constraints than TAM model and so the model can offer a comprehensive view of the variables present in UTAUT which can influence user adoption and use of m-banking services in Zambia.

\section{Acknowledgements}

I acknowledge the valuable assistance and support of the following: All research participants.

\section{Conflicts of Interest}

The authors declare no conflicts of interest regarding the publication of this paper.

\section{References}

[1] Al-Akhras, T.M., Al-Saiyeed, R., Alian, M. and Qwasmi, D. (2011) Innovative Secure Mobile Banking Services. 195. https://doi.org/10.3991/ijim.v5i1.1516

[2] Hoehle, H. and Huff, S. (2012) Advancing Task-Technology Fit Theory: A Formative Measurement Approach to Determining Task Channel Fit for Electronic Banking Channels. In: Hart, D.N. and Gregor, S.D., Eds., Information Systems Foundations. Theory Building in Information Systems, ANU Press, Canberra, 133-170. https://doi.org/10.22459/ISF.10.2012.06

[3] Tam, C. and Oliveria, T. (2017) Literature Review of Mobile Banking and Individual Performance. International Journal of Marketing, 35, 1041-1065. https://doi.org/10.1108/IJBM-09-2015-0143

[4] Financial Sector Deepening Zambia (2018) Demand, Supply \& Regulation: Financial Inclusion Summary Report.

[5] FinScope (2015) FinScope Survey Zambia 2015.

[6] Bank of Zambia (2017) Annual Report, Lusaka, Zambia.

[7] Lusaka Times (2018) Zambia's Mobile Phone Sector in Near Saturation-ZICTA.

[8] Rogers, E.M. (1995) Diffusion of Innovations. 4th Edition, The Free Press, New York, 518.

[9] Fishbein, M. and Ajzen, I. (1975) Belief, Attitude, Intention, and Behaviour: An Introduction to Theory and Research. Addison-Weasly, Reading.

[10] Ajzen, I. (1991) The Theory of Planned Behavior. Organization Behavior and Human Decision Processes, Academic Press, Inc., Cambridge, 179-211. https://doi.org/10.1016/0749-5978(91)90020-T

[11] Taylor, S. and Todd, P.A. (1995) Understanding Information Technology Usage: A Test of Competing Models. Information Systems Research, 6, 144-176. https://doi.org/10.1287/isre.6.2.144

[12] Chuttur, M.Y. (2009) Overview of the Technology Acceptance Model: Origins, Developments and Future Directions, Indiana University, USA. Sprouts. Working papers on Information Systems, 9.

[13] Davies, F. (1985) A Technology Acceptance Model for Empirically Testing New End-User Information Systems: Theory and Results. Unpublished Doctorial Dissertation, MIT Sloan School of Management, Cambridge.

[14] Lee, Y., Kozar, K.A. and Larsen, K.R.T. (2003) The Technology Acceptance Model: Past, Present, and Future. Communications of the AIS, 12, 752-780. 
https://doi.org/10.17705/1CAIS.01250

[15] Lema, A. (2017) Factors Influencing the Adoption of Mobile Financial Services in the Unbanked Population. International Journal of humanities and Social Sciences, 12, Article 50. http://aisel.aisnet.org/cais/vol12/iss1/50

[16] Ramburn, H. and Van belle, J. (2011) Use and Adoption of Mobile Data Services in Africa: An Empirical Study in Mauritius and South Africa. International Journal of e-Education, e-Business, e-Management and e-Learning, 1, 28-34. https://doi.org/10.7763/IJEEEE.2011.V1.5

[17] Onyebuchi, B., et al. (2016) Mobile Banking-Adoption and Challenges in Nigeria. International Journal of Innovative Social Sciences and Humanities Research, 4, 17-27.

[18] Makanyeza, C. (2017) Determination of Consumers' Intention to Adopt Mobile Banking Services in Zimbabwe. International Journal of Bank Marketing, 35, 997-1017. https://doi.org/10.1108/IJBM-07-2016-0099

[19] Mwiya, B., Chikumbi, F., Shikaputo, C., Kabala, E., Kaulung’ombe, B. and Siachinji, B. (2017) Examining Factors Influencing E-Banking Adoption: Evidence from Bank Customers in Zambia. American Journal of Industrial and Business Management, 7, 741-759. https://doi.org/10.4236/ajibm.2017.76053

[20] Munoz-Leiva, et al. (2017) Determinants of Intention to Use the Mobile Banking Apps: An Extension of the Classic TAM Model. Spanish Journal of Marketing, 27, 25-38. https://doi.org/10.1016/j.sjme.2016.12.001

[21] Lusaya, S. and Kalumba, B. (2018) The Challenges of Adopting the Use of E-Banking to the Customers: The Case of Kasama District Banking Customers. Scholar Journal of Applied Sciences and Research, 1, 26-31.

[22] Shaikh, A. and Karjaluoto, H. (2015) Mobile Banking Adoption: A Literature Review. Telematics and Information, 32, 129-142.

https://doi.org/10.1016/j.tele.2014.05.003

[23] Soneka, P.N. and Phiri, J. (2019) A Model for Improving E-Tax Systems Adoption in Rural Zambia Based on the Tax Model. Open Journal of Business and Management, 7, 908-918. https://doi.org/10.4236/ojbm.2019.72062

[24] Daka, C.G. and Phiri, J. (2019) Factors Driving the Adoption of E-Banking Services Based on the UTAUT Model. International Journal of Business and Management, 14, 43-52. https://doi.org/10.5539/ijbm.v14n6p43

[25] Krejcie, R.V. and Morgan, D.W. (1970) Determining Sample Size for Research Activities. Educational and Psychological Measurement, 30, 607-610. https://doi.org/10.1177/001316447003000308 